\title{
Consensus
}

Volume 31

Issue 1 Preaching the Gospel in Canada in the 21st

Article 19

Century

$5-1-2006$

\section{Perspectives old and new on Paul: the "Lutheran" Paul and his critics}

Oscar Cole-Arnal

Follow this and additional works at: http://scholars.wlu.ca/consensus

\section{Recommended Citation}

Cole-Arnal, Oscar (2006) "Perspectives old and new on Paul: the "Lutheran" Paul and his critics ," Consensus: Vol. 31 : Iss. 1 , Article 19.

Available at: http://scholars.wlu.ca/consensus/vol31/iss1/19

This Book Reviews is brought to you for free and open access by Scholars Commons @ Laurier. It has been accepted for inclusion in Consensus by an authorized editor of Scholars Commons @ Laurier. For more information, please contact scholarscommons@wlu.ca. 
refuses to wallow in a sentimentality that acts as if the world were still enchanted.

As a teacher of preaching, I find it refreshing to find a work by a historian that takes seriously the media by which we hear and appropriate the Reformation Gospel of God's grace. While Matheson's book occasionally tends to the romantic (as is the wont of books about imagination), he often just as quickly checks himself and properly reminds readers of the contradictions and ironies that make history what it is. I recommend the book highly for those who wish to consider in a new way not just what but how the Reformation might be meaningful for us today.

David Schnasa Jacobsen

Waterloo Lutheran Seminary

\section{Perspectives Old and New on Paul: The "Lutheran" Paul and His Critics \\ Stephen Westerholm \\ Grand Rapids, Michigan: Eerdmans, 2004 \\ 508 pages, $\$ 42$ Paperback}

I recently had the pleasure of teaching a one-term course on Paul and his letters, for which Westerholm's fine work on how Paul has been interpreted for the last two thousand years proved to be a superb resource. I recommend it to all who have interests in the historical Paul of the first century, but especially those who seek to understand the impact of the apostle to the Gentiles in the subsequent history of the Christian church, in the scholarly world, and in the recent explosion of healthy Jewish-Christian dialogue.

To be sure, this is not a New Testament text as such; rather it falls more comfortably into the realm of the history of ideas. After all, the book begins with an analysis of how Augustine understood and used Paul. Nonetheless, it remains a valuable work for New Testament scholars in at least two respects.

First, in the last extensive section of his work ("Part III: The Historical and the 'Lutheran' Paul"), Westerholm provides an indepth analysis of the Pauline corpus in relation to the very 
terminology that so grabbed and drove Martin Luther in the sixteenth century: the righteousness of God, the Law, and of course, justification by faith. After covering such great historical thinkers as Augustine, Luther, John Calvin and John Wesley, he turns to various conflicting visions of Paul found in the twentieth century, and in this section we find a focus almost entirely on the New Testament scholarly community. Beginning with such pioneering giants as Wilhelm Wrede and Albert Schweitzer he moves swiftly into that scholarship (both Jewish and Christian) which continues to define the debate on Paul from the Bultmann School and its critics up to the present. From a bird's-eye view, this grand summary of Pauline impact from Augustine to our current day is masterful and flawless.

Other details deserve similar high praise. In order for Westerholm to use the designation, "the Lutheran Paul," in the subtitle of the book, he needed to present a thorough and balanced account of Luther's own perceptions and use of the apostle. Had he not, the book would have collapsed. The section on Luther held up very well. Westerholm brilliantly demonstrates the historical continuity of Luther's dominance in Pauline hermeneutics in his examination of such twentieth century figures as Rudolf Bultmann and his most renowned pupil, Ernst Käsemann. Moreover the author deftly handles the challenges to Bultmannian dominance in his discussion of such figures as Krister Stendahl and E. P. Sanders. I was pleased and refreshed by his inclusion of high profile Jewish scholars of Paul such as Hans Joachim Schoeps and the more recent Daniel Boyarin. His bibliography of well-known Pauline scholars and their works provides a valuable tool for interested readers.

Westerholm's study provides a powerfully balanced account that treats the entire range of Pauline scholars with integrity and respect. I have one criticism: I believe that that the study needs to begin not with Augustine but rather with that most controversial Marcion who challenged the young Jesus Movement with his own brand of bifurcated radical Paulinism.

In my judgment Perspectives Old and New on Paul lies on that thin border between required and highly recommended reading for a course text on Paul. This is especially true, I believe, for those within the Lutheran tradition. Although I chose another book on Paul for required reading in my course (one that focussed on the first century context), nonetheless I promoted this book unequivocally for my 
students' continued study and vocation. In the interim that positive opinion of Westerholm's work has not changed.

Oscar Cole-Arnal

Waterloo Lutheran Seminary

Waterloo, Ontario

\section{Martin Bucer: A Reformer and his Times}

Martin Greschat

Translated by Stephen E. Buckwalter

Louisville: Westminster John Knox Press, 2004 (1990).

Pp. xii $+334, \$ 42$ Paperback

Westminster John Knox Press has performed a commendable service in producing this English translation of Martin Greschat's definitive work on the Strasbourg reformer Martin Bucer Martin Bucer: Ein Reformator und seine Zeit which came out fifteen years ago. Although studies of Bucer have fallen habitually into the category of second-level reformers, one notch below such giants as Luther and Calvin, Greschat's work underscores the opinion of numerous academics (self included) who believe that Bucer stands out in the period as another such giant both in his influence at the time and in his vision so often alien to his time. Although the author himself does not take this position in an obvious way he does demonstrate it with a wealth of detail and analysis.

Although I find some significant weaknesses in the book, my opinion of it remains overwhelmingly positive. For me, the major weakness is one I find in all too many books. The author seems relatively unaware of any significant role played by women in the Strasbourg Reformation. Katharina Zell, controversial wife of the city pastor Matthieu Zell, receives a bare mention only three times. Even though Dr. Greschat calls her "the indomitable Katharina Zell (225)," we find virtually no fleshing out whatsoever of her influential correspondence, her courageous support of Reformation pluralism which well surpassed that of Bucer, her writings, and her care for marginalised people including refugees from the Peasants' War. Although the book is a biography of Bucer, most other male reformers mentioned receive more substantial analysis than 